\title{
EARLY SELECTION OF FULL-SIB POTATO FAMILIES
}

\author{
Seleção precoce de famílias de irmãos-completos de batata
}

\author{
Dheyne Silva Melo', César Augusto Brasil Pereira Pinto ${ }^{2}$, Leandro Santos Peixouto ${ }^{3}$, \\ Diogo Gonçalves Neder ${ }^{4}$, Josiane Cristina de Assis $^{5}$
}

\begin{abstract}
Clonal selection is the preferred breeding method used in potatoes (Solanum tuberosum L.). However this selection procedure is only efficient for more advanced generations and shows no good results when applied in the seedling up to the second clonal generation. This study assessed the feasibility of selection in early generations of full-sib potato families and compares the selection method among and within families with the combined selection under different selection intensities. Six experiments were conducted from the first (C1) until the third clonal generation (C3). In $\mathrm{C} 1$ a randomized complete block design with four replications of 25 plants was used. In the remaining generations RCB was employed with three replications of 10 plants. Genetic variances were lower between families than within families, for all traits, but the heritabilities between families were almost always larger. The expected gains from selection between and within families were superior to gains from the combined selection in any intensity of selection. The selection of families should have weaker intensity than selection among clones within families. The selection of families was more efficient when based on the average of environments.
\end{abstract}

Index terms: Solanum tuberosum, plant breeding, clonal generations.

\section{RESUMO}

A seleção clonal é o método de melhoramento preferencialmente usado no melhoramento da batata (Solanum tuberosum L.). Contudo, esse método de seleção somente é eficiente em gerações avançadas e não apresenta bons resultados quando aplicado da geração seedling até a segunda geração clonal. Objetivou-se, neste trabalho, verificar a viabilidade da seleção de famílias em gerações precoces e comparar o método de seleção entre e dentro de famílias com a seleção combinada, sob diferentes intensidades de seleção. Seis experimentos foram conduzidos desde a primeira (PGC) até a terceira geração clonal. Na PGC, o delineamento foi DBC com quatro repetições e parcelas de 25 plantas. Nas demais gerações, empregaram-se DBC com três repetições e parcelas de 10 plantas. As variâncias genéticas entre famílias foram menores que dentro de famílias para todas as características, mas as herdabilidades entre famílias foram quase sempre maiores. Os ganhos esperados com a seleção entre e dentro de famílias foram superiores aos ganhos com a seleção combinada, sob qualquer intensidade. A seleção entre famílias deve ter intensidade mais fraca que a seleção entre clones dentro de famílias, sendo ela mais eficiente, quando baseada na média dos ambientes.

Termos para indexação: Solanum tuberosum, melhoramento de plantas, gerações clonais.

\section{(Received in august 29, 2011 and approved in october 31, 2011)}

\section{INTRODUCTION}

In any breeding program, reducing the time spent obtaining superior genotypes is of fundamental importance. In potato breeding programs, clonal selection is the most utilized method, the main limitation being the time taken to obtain elite genotypes. The high interaction between genotypes and clonal generations, most intense in the early generations, requires the multiplication of potato seed until third or fourth clonal generation, when clones show greater stability for the traits of agronomic importance (LAMBERT et al., 2006a). At the same time, the experimental precision in the initial stages of improvement $(\mathrm{C} 1$ and $\mathrm{C} 2)$ is reduced due to the large number of clones to be evaluated in small plots, because of the minute quantity of seed tubers obtained from each clone. Selecting families from these assessments can be performed earlier in the $\mathrm{C} 1$ or $\mathrm{C} 2$, since the intensity of selection is not very strong. The study of interaction is very important in breeding programs, because the breeder has the option of selecting stable, adapted and productive genotypes. Thus the proposed alternative is a family-based selection, on the evaluation of a sample of clones whose average identifies them as superior families, which should have a higher number of promising clones. Only after the selection of the best families will their respective clones be assessed individually (clonal selection). Many authors have commented that no new cultivars have been selected from

${ }^{1}$ Empresa Brasileira de Pesquisa Agropecuária/Embrapa - Agroindústria Tropical - Fortaleza - CE - Brasil

2Universidade Federal de Lavras/UFLA - Departamento de Biologia/DBI - Cx. P. 37 - 37200-000 - Lavras - MG - Brasil - cesarbrasil@dbi.ufla.br

${ }^{3}$ Instituto Federal de Educação, Ciência e Tecnologia Baiano/IFBAIANO - Guanambi - BA - Brasil

${ }^{4}$ Universidade Federal Rural de Pernambuco/UFRPE - Recife - PE - Brasil

${ }^{5}$ Centro Universitário do Planalto de Araxá/UNIARAXÁ - Araxá - MG - Brasil

Ciênc. agrotec., Lavras, v. 35, n. 6, p. 1101-1109, nov./dez., 2011 
families with low averages (GOPAL, 1997; BRADSHAW et al., 2000; DINIZ et al., 2006) which reinforces the usefulness of family selection. This method increases the probability of selecting superior genotypes, since they use smaller, more precise experiments, in designs with replications and can be planted in more than one location or season.

This study aimed to verify the feasibility of selection in early generations of families, to compare selections between and within families with the combined selection, using different selection intensities.

\section{MATERIALS AND METHODS}

True seeds from 22 full-sib families were used to form the seedling generation. The botanical seeds were treated with gibberellic acid, 1500 ppm for 24 hours, dried and sown in plastic trays. After 30 days, the seedlings were transplanted to trays containing an organo-mineral substrate. When the seedlings reached $10-12 \mathrm{~cm}$ in height they were transplanted again to $10 \mathrm{~cm}$ diameter pots for tuberization. After plant senescence, tubers were harvested and stored at $4^{\circ} \mathrm{C}$ and $85 \%$ relative humidity for future experiments in the field.

The 22 clonal families were evaluated by three clonal generations, totaling six field experiments in the state of Minas Gerais, Brazil. Soil preparation and correction through lime, fertilization, controlling diseases and weeds, and irrigation were conducted according to recommendations for the crop.

The first clonal generation (C1), was conducted from February to May 2005 (dry season) in Carrancas, MG, in a commercial production farm, located at $1052 \mathrm{~m}$ altitude, $21^{\circ}$ 29 'S latitude and $44^{\circ} 38^{\prime} \mathrm{W}$ longitude. The experimental design comprised of fully randomized blocks with four replications. The plots had 25 plants, spaced $0.5 \mathrm{~m}$ x $0.8 \mathrm{~m}$. In each block there was a plot of controls which consisted of the cultivars Monalisa, Atlantic and Asterix and the clones CBM 16-16 and CBM 09-10 from the breeding Program at the Federal University of Lavras (UFLA). Each control was represented by five plants, totaling 25 plants per plot. In this step we only evaluated the characteristic tuber yield.

In the second clonal generation $(\mathrm{C} 2)$, two experiments were conducted from September to December 2005 (rainy season). One at the experimental area of the Biology Department (DBI) at Ufla, Lavras, MG, $910 \mathrm{~m}$ altitude, $21^{\circ}$ 16'S latitude and $44^{\circ} 58^{\prime} \mathrm{W}$ longitude, and the other in São João da Mata, MG, in a commercial production farm, located at $1200 \mathrm{~m}$ altitude, $21^{\circ} 55^{\prime} \mathrm{S}$ latitude and $45^{\circ} 57^{\prime} \mathrm{W}$ longitude. The experimental design comprised of fully randomized blocks with three replications. The plots had 10 plants; spaced $0.5 \mathrm{~m}$ x $0.8 \mathrm{~m}$. Reducing the number of plants per plot was necessary, since the clones were divided to conduct the two experiments. The control cultivars were Monalisa, Atlantic, Asterix and Agata. The other experiment conducted in São João da Mata, did not use Agata. Evaluations for traits of tuber yield (TY), percentage of large tubers (PLT) and tuber specific gravity (TSG) were made.

The three experiments of the third clonal generation (C3) were conducted from May to August 2006 (winter crop) in Lavras, in the experimental area of DBI Ufla, in Alfenas, in a commercial production farm, located about $881 \mathrm{~m}$ altitude, $21^{\circ} 25^{\prime} \mathrm{S}$ latitude and $45^{\circ} 57^{\prime} \mathrm{W}$ longitude, and in Careaçu, in a commercial production farm as well, located at $816 \mathrm{~m}$ altitude, $22^{\circ} 02^{\prime} \mathrm{S}$ latitude and $45^{\circ} 42^{\prime} \mathrm{W}$ longitude. The experiments conducted were identical to C2. The controls consisted of the cultivars Monalisa, Atlantic and Asterix.

The means from the 22 families were considered in each environment for the joint analysis of variance. The Bartlett test was applied according to Ramalho et al. (2000), to certify the homogeneity of the mean square errors of individual analysis. The treatment effects were considered random. Genetic parameters were estimated from expected mean squares. To estimate the expected gains from family selection we used the expression of Falconer and Mackay (1996):

$$
\mathrm{GS}_{\text {families }}=\mathrm{i}_{\mathrm{N}} \sigma_{\overline{\mathrm{P}}} \mathrm{h}_{\mathrm{f}}^{2}
$$

In where:

$G S_{\text {families }}$ : the expected gain with family selection; $i_{N}$ : standardized selection intensity, obtained from the table of Fisher and Yates (1971), corrected for small sample size $(\mathrm{N}<50)$ by the expression of Wricke and Weber (1986):

$\mathrm{i}_{\mathrm{N}}=\mathrm{i}-\frac{1-\mathrm{f}}{2 \times \mathrm{i} \times \mathrm{f} \times(\mathrm{N}+1)}$

in which:

$i$ : standardized selection intensity for large populations, obtained from the table of Fisher and Yates (1971)

$f$ : proportion selected,

$N$ : number of individuals.

$\sigma_{\bar{P}}$ : Phenotypic standard deviation of the families means; $h_{f}^{2}$ : heritability among families.

To estimate the expected gains from clonal selection, we used the formula from Falconer and Mackay (1996):

$$
\mathrm{GS}_{\text {clonal }}=\mathrm{i} \sigma_{\mathrm{w}} \mathrm{h}_{\mathrm{w}}^{2}
$$

where:

$G S_{\text {clonal }}$ :expected gain with selection of clones; 
$i$ : standardized selection intensity, obtained from the table of Fisher and Yates (1971).

$\sigma_{w}$ : Phenotypic standard deviation within families;

$h_{w}^{2}$ : heritability within families.

To compare the selection between and within families with the combined selection, we used different selection intensities, so that the same numbers of clones were selected at the end of the two selection processes.

Estimates of the expected gains from selection between and within families were obtained from:

$$
\mathrm{GS}_{\text {between+within }}=\mathrm{GS}_{\text {families }}+\mathrm{GS}_{\text {clonal }}
$$

To estimate the expected gains from selection within families, we used the same expression of expected gains from clonal selection. The expected gains from the combined selection were adapted from Bueno Filho and Vencovsky (2000), as the following expression

$$
\mathrm{GS}_{\text {combined }}=\mathrm{i} \frac{\sigma_{\mathrm{f}}^{2}\left(\frac{\mathrm{i}-1}{\mathrm{i}}\right) \mathrm{h}_{\mathrm{f}}^{2}+\sigma_{\mathrm{w}}^{2}\left(\frac{\mathrm{k}_{\mathrm{h}}-1}{\mathrm{k}_{\mathrm{h}}}\right)\left(\frac{\mathrm{h}_{\mathrm{e}}^{2}}{\mathrm{r}_{\mathrm{h}} \mathrm{k}_{\mathrm{h}}}+\mathrm{h}_{\mathrm{w}}^{2}\right)}{\sqrt{\mathrm{MS}_{\text {within }}\left(\frac{\mathrm{k}_{\mathrm{h}}-1}{\mathrm{k}_{\mathrm{h}}}\right)\left(\mathrm{h}_{\mathrm{w}}^{2}\right)^{2}+\frac{\mathrm{MS}_{\text {families }}}{\mathrm{r}_{\mathrm{h}} \mathrm{k}_{\mathrm{h}}}\left(\frac{\mathrm{i}-1}{\mathrm{i}}\right)\left(\mathrm{h}_{\mathrm{f}}^{2}\right)^{2}}}
$$

where:

$G S_{\text {combined }}$ : the expected gain with combined selection; $i$ : standardized selection intensity, obtained from the table of Fisher and Yates (1971);

$\sigma_{f}^{2}$ : genetic variance among families;

$\sigma_{w}^{2}$ : genetic variance within families;

$h_{w}^{2}$ and $h_{f}^{2}$ : heritability within families and between families respectively;

$M S_{\text {within }}$ : mean square within families;

$M S_{\text {families }}^{\text {within }}$ : mean square of families,

$i$ : number of families;

$r_{h}, k_{h}$ : harmonic mean of the number of replicates and plants, respectively.

The gains for combined selection were only estimated for the trait tuber yield, using final selection intensities of $5 \%$ and $10 \%$.

\section{RESULTSAND DISCUSSION}

Joint analysis showed the significance of the interaction between families and environments for the traits percentage of large tubers and tuber specific gravity, indicating that families did not show coincidental behavior in different environments (Table 1).
This means that families may have specific adaptation to particular environments. This specific adaptation in potato breeding programs can generally only be assessed if the family selection method is applied. In clonal selection, due to the short propagation material available and the large number of genotypes to be evaluated you can rarely make selections in more than one environment, for generations $\mathrm{C} 1$ and $\mathrm{C} 2$. The clones will only be assessed in more environments when they are already well advanced in stages (C3 or $\mathrm{C} 4)$. Thus the selection of families has an advantage over clonal selection, which is very desirable in potato breeding programs.

Sekioka and Lauer (1970) when evaluating five potato cultivars in four environments for a period of three years, found a significant interaction between genotypes, locations and years for all traits. Tai et al. (1981) also found strong genotype $\mathrm{x}$ environment interaction for tuber yield, which indicates that the genotypes behaved differently in relation to environmental effects. In this study the interaction families $\mathrm{x}$ environments for tuber yield was not significant, a result also found by Simon et al. (2009) when evaluating open-pollinated families in the state of Minas Gerais. However, data from the literature indicate that the predominant interaction of genotypes $\mathrm{x}$ environments is significant for tuber yield (ORTIZ; GOLMIRZAIE, 2004; LAMBERT et al., 2006ab). In breeding programs of sugar cane, while focusing on the selection of families, the family and environment interaction has been highly significant for most traits (JACKSON et al., 1995; BRESSIANI et al., 2002). With sugar cane, the selection of families has been widely used with positive results (JACKSON et al., 1995; KIMBENG; COX, 2003).

The magnitude of the heritability of all traits between families ranged from 0.66 to 0.88 (Table 1 ) which have always been higher than the heritability within families, as in clonal selection, suggesting that the selection of families would provide more reliable gains in the early stages of the breeding program (BRADSHAW et al., 1998; GOPAL, 2001; DINIZ et al., 2006). According to Simmonds (1996), discrimination of variation between families is more efficient than the discrimination of the variation between individuals of the same family as the environmental effect is lower among families than among individuals of the same family. The superiority of the heritability for family selection in potato in relation to the clonal selection is presented in the works of Simmonds (1996), Gopal (1997), Bradshaw et al. (2000), Simon et al. (2009). Due to the superiority of heritability at the families level the selection will prove even more efficient for the characteristics evaluated with a low heritability. 
Table 1 - Summary of joint analysis of variance for TY, PLT and TSG, and estimates of environmental variance ( $\left.\sigma_{e}^{2}\right)$, genetic variances between $\left(\sigma_{f}^{2}\right)$ and within families $\left(\sigma_{w}^{2}\right)$, heritability between $\left(h_{f}^{2}\right)$ and within $\left(h_{w}^{2}\right)$ families and their respective confidence intervals ( $C I_{h_{f}^{2}}$ and $\left.C I_{h_{w}^{2}}\right)$.

\begin{tabular}{|c|c|c|c|c|c|}
\hline Sources of Variation & $\mathrm{DF}^{1}$ & $\mathrm{DF}^{2}$ & & MS & \\
\hline & & & TY $\left(\mathrm{g} \mathrm{pl}^{-1}\right)^{1}$ & PLT $(\%)^{1}$ & $\mathrm{TSG}^{2}$ \\
\hline Blocks/ Environments & 10 & 8 & 974728.95 & 682.08 & $2.92 \times 10^{-4}$ \\
\hline Environments & 4 & 3 & $10485120.52^{* *}$ & $21781.66^{* *}$ & $3.83 \times 10^{-2 * *}$ \\
\hline Families & 21 & 21 & $2395795.50^{* *}$ & $4709.25^{* *}$ & $1.35 \times 10^{-3 * *}$ \\
\hline Families x Environments & 84 & 63 & $279518.98^{\mathrm{ns}}$ & $1486.55^{* *}$ & $4.64 \times 10^{-4 * *}$ \\
\hline Average error & 248 & 198 & 328500.86 & 965.26 & $2.00 \times 10^{-4}$ \\
\hline Average error within & 2676 & 2081 & 244222.96 & 861.52 & $1.45 \times 10^{-4}$ \\
\hline Averages & & & 857.4 & 48.3 & 1.072 \\
\hline $\mathrm{CV}(\%)$ & & & 23.6 & 22.7 & 0.5 \\
\hline$\sigma_{e}^{2}$ & & & 137609.79 & 605.22 & $5.86 \times 10^{-5}$ \\
\hline$\sigma_{f}^{2}$ & & & 92339.72 & 140.62 & $4.00 \times 10^{-5}$ \\
\hline$h_{f}^{2}$ & & & 0.88 & 0.68 & 0.66 \\
\hline$C I_{h_{f}^{2}}$ & & & $(0.78-0.95)$ & $(0.41-0.85)$ & $(0.34-0.84)$ \\
\hline$\sigma_{w}^{2}$ & & & 106613.17 & 256.30 & $8.59 \times 10^{-5}$ \\
\hline$h_{w}^{2}$ & & & 0.44 & 0.30 & 0.59 \\
\hline$C I_{h_{w}^{2}}$ & & & $(0.32-0.53)$ & $(0.15-0.41)$ & $(0.50-0.67)$ \\
\hline
\end{tabular}

${ }^{1,2}$. Degrees of freedom for the traits evaluated, ** Significant at $1 \%$ probability, ns non significant by the $\mathrm{F}$ test. $\sigma_{e}^{2}$ - environmental variance.

Estimates of the expected gains from selection of the top six families, the 600 best clones selected in $\mathrm{C} 1$ and the 180 best clones selected in other generations (considering a final selection intensity of $27 \%$ in each of the experiments and on their average for the traits tuber yield), percentage of large tubers and tuber specific gravity are presented in Table 2. Gains were estimated for all traits (direct selection), regardless of the breeding method used. The gains for tuber specific weight seem low when compared with the estimates for other traits, but it is noteworthy that an increase of 0,005 units in the value of this feature causes a $1 \%$ increase in dry matter content of tubers, which is highly desirable, especially if the breeder's goal is to get cultivars to be used in the fried-product industry.

Considering the selection in individual environments, clonal selection was, in most cases more efficient than the selection of families. This superiority occurred because the phenotypic variance within families, used to estimate the expected response with clonal selection, was far superior to the phenotypic variance between families, which inflated the estimated gain. But this is not an ideal form of family selection, because one of its advantages over clonal selection is the ability to select from a variety of environments from the early generations. In clonal selection, evaluating more than one environment is possible only in advanced stages of selection, i.e., the interaction can only be estimated and used in the selection of elite genotypes.

The selection based on the average of environments for families selection stood out in relation to the method of clonal selection. This occurred because only families were being repeated in all environments, increasing the likelihood of success in the selection. Thus, if the breeder chooses the selection of families in early generations, he should base his selection on the average of all environments, not just the average of a particular environment. This type of selection in more than one environment is most desired as it not only provides information about stability and adaptability, it will also provide more accurate results because the data used are from various experiments (localities and/or crop seasons) thus increasing the number of replications of each family. 
Table 2 - Means and estimated expected gains for families selection $\left(\mathrm{GS}_{\text {families }}\right)$ and clonal selection $\left(\mathrm{GS}_{\text {clonal }}\right)$, through the selection of the top six families and the best clones (selection intensity $=27.3 \%$ ) in absolute figures and in percentages, in each experiment and on their average for tuber yield (TY), percentage of large tubers (PLT) and tuber specific gravity (TSG).

\begin{tabular}{|c|c|c|c|c|c|c|}
\hline \multirow{2}{*}{ Generations } & \multirow{2}{*}{ Localities } & \multicolumn{5}{|c|}{ TY $\left(\mathrm{g} \mathrm{pl}^{-1}\right)$} \\
\hline & & Averages & $\mathrm{GS}_{\text {families }}$ & $\%$ & $\mathrm{GS}_{\text {clonal }}$ & $\%$ \\
\hline $\mathrm{C} 1$ & Carrancas & 504.2 & 64.0 & 12.7 & 47.4 & 9.4 \\
\hline \multirow{2}{*}{$\mathrm{C} 2$} & Lavras & 612.0 & 83.4 & 13.6 & 107.4 & 17.6 \\
\hline & São João da Mata & 914.8 & 98.2 & 10.7 & 141.3 & 15.4 \\
\hline \multirow{3}{*}{$\mathrm{C} 3$} & Lavras & 899.0 & 167.4 & 18.6 & 317.2 & 35.3 \\
\hline & Alfenas & 990.8 & 64.0 & 6.5 & 335.8 & 33.9 \\
\hline & Careaçu & 870.5 & 152.7 & 17.5 & 388.9 & 44.7 \\
\hline \multicolumn{2}{|c|}{ Averages of all experiments } & 857,4 & 334.4 & 39.0 & 262.9 & 30.7 \\
\hline \multirow{2}{*}{ Generations } & \multirow{2}{*}{ Localities } & \multicolumn{5}{|c|}{ PLT (\%) } \\
\hline & & Averages & $\mathrm{GS}_{\text {families }}$ & $\%$ & $\mathrm{GS}_{\text {clonal }}$ & $\%$ \\
\hline \multirow{3}{*}{$\mathrm{C} 2$} & Lavras & 49.8 & 9.0 & 18.2 & 9.9 & 19.9 \\
\hline & São João da Mata & 50.0 & 5.2 & 10.3 & 15.4 & 30.9 \\
\hline & Lavras & 49.6 & 6.4 & 13.0 & 10.3 & 20.7 \\
\hline \multirow[t]{2}{*}{ C3 } & Alfenas & 54.9 & 5.2 & 9.4 & 19.6 & 35.7 \\
\hline & Careaçu & 37.3 & 6.5 & 17.5 & 5.7 & 15.3 \\
\hline \multicolumn{2}{|c|}{ Média de todos os experimentos } & 48.3 & 11.5 & 23.8 & 10.7 & 22.1 \\
\hline \multirow{2}{*}{ Generations } & \multirow{2}{*}{ Localities } & \multicolumn{5}{|c|}{ TSG } \\
\hline & & Averages & $\mathrm{GS}_{\text {families }}$ & $\%$ & $\mathrm{GS}_{\text {clonal }}$ & $\%$ \\
\hline \multirow{2}{*}{$\mathrm{C} 2$} & Lavras & 1.060 & 0.006 & 0.6 & - & - \\
\hline & São João da Mata & 1.071 & 0.003 & 0.2 & - & - \\
\hline \multirow{3}{*}{$\mathrm{C} 3$} & Lavras & 1.079 & 0.005 & 0.4 & 0.015 & 1.4 \\
\hline & Alfenas & 1.076 & 0.004 & 0.4 & 0.001 & 0.1 \\
\hline & Careaçu & 1.078 & 0.006 & 0.5 & 0.006 & 0.5 \\
\hline \multicolumn{2}{|c|}{ Média de todos os experimentos } & 1,072 & 0.006 & 0.6 & 0.009 & 0.8 \\
\hline
\end{tabular}

According to Simon et al. (2009) selecting the average of all environments evaluated provided high genetic progress, especially for tuber yield. The authors stated that selection based on the average of environments tends to explore the promising group of clones with general adaptation, which in commercial terms, is more viable because a cultivar is explored in a wide range of environments. In sugar cane, which uses the same criteria for selection as potatoes, Bressiani et al. (2002) concluded that the expected progress based on the average of environments was always greater than for a specific environment. For the traits and conditions evaluated by these authors, selection in one environment and planting in another would reduce the population mean. This result reinforces the need to use more than one environment for family selection, as the results of selection - the elite clones - will be used in a wider range of environments other than that in which they were assessed.
Estimates of the expected gains from selection between and within families and the combined selection for tuber yield in each environment and their average (using different selection intensities) are presented in Table 3. It is observed that in most situations, the selection between and within families was slightly more efficient than the combined selection, contrary to what is commonly found in literature (FALCONER; MACKAY, 1996; PIRES et al., 1996; PAULA et al., 1998). These authors also reported that the combined selection process is especially appropriate in cases where it has low variability within families, which did not happen to families in this study. Thus, the selection between and within families should be preferred as a method of selection. It is also important to mention that, despite the superiority of selection between and within families, the combined selection process also provided significant gains which could also be used. 
Table 3 - Estimates of the expected gains for tuber yield for families selection $\left(\mathrm{GS}_{\text {families }}\right)$, and clonal selection $\left(\mathrm{GS}_{\text {clonal }}\right)$, selection between and within families $\left(\mathrm{GS}_{\text {bet+wit }}\right)$ and combined selection $\left(\mathrm{GS}_{\text {comb }}\right)$ using different selection intensities (SI in \%) in each experiment and on their overall average.

\begin{tabular}{|c|c|c|c|c|c|c|c|}
\hline Generations & Localities & $\mathrm{SI}_{\text {between }}$ & $\mathrm{GS}_{\text {families }}$ & $\mathrm{SI}_{\text {within }}$ & $\mathrm{GS}_{\text {within }}$ & $\mathrm{GS}_{\text {bet+wit }}$ & $\overline{\mathrm{GS}_{\mathrm{comb}}}$ \\
\hline $\mathrm{C} 1$ & Carrancas & \multirow{7}{*}{$10 \%$} & 17.8 & \multirow{7}{*}{$50 \%$} & 6.2 & 24.0 & 22.5 \\
\hline \multirow{2}{*}{$\mathrm{C} 2$} & Lavras & & 19.1 & & 11.5 & 30.6 & 26.6 \\
\hline & São João da Mata & & 15.1 & & 10.1 & 25.2 & 21.4 \\
\hline \multirow{3}{*}{ C3 } & Lavras & & 26.1 & & 23.1 & 49.2 & 40.8 \\
\hline & Alfenas & & 9.1 & & 22.2 & 31.3 & 28.6 \\
\hline & Careaçu & & 24.6 & & 29.3 & 53.9 & 44.8 \\
\hline \multicolumn{2}{|c|}{ Averages of all experiments } & & 54.7 & & 20.1 & 74.8 & 69.4 \\
\hline $\mathrm{C} 1$ & Carrancas & \multirow{7}{*}{$20 \%$} & 14.5 & \multirow{7}{*}{$25 \%$} & 9.8 & 24.3 & 22.5 \\
\hline \multirow{2}{*}{$\mathrm{C} 2$} & Lavras & & 15.6 & & 18.3 & 33.9 & 26.6 \\
\hline & São João da Mata & & 12.3 & & 16.1 & 28.4 & 21.4 \\
\hline \multirow{3}{*}{$\mathrm{C} 3$} & Lavras & & 21.3 & & 36.8 & 58.1 & 40.8 \\
\hline & Alfenas & & 7.4 & & 35.4 & 42.8 & 28.6 \\
\hline & Careaçu & & 20.0 & & 46.6 & 66.6 & 44.8 \\
\hline \multicolumn{2}{|c|}{ Averages of all experiments } & & 44.6 & & 32.0 & 76.6 & 69.4 \\
\hline $\mathrm{C} 1$ & Carrancas & \multirow{6}{*}{$25 \%$} & 13.2 & & 10.8 & 24.0 & 22.5 \\
\hline \multirow{2}{*}{$\mathrm{C} 2$} & Lavras & & 14.2 & & 20.2 & 34.4 & 26.6 \\
\hline & São João da Mata & & 11.2 & & 17.7 & 28.9 & 21.4 \\
\hline \multirow{3}{*}{ C3 } & Lavras & & 19.4 & $20 \%$ & 40.5 & 59.9 & 40.8 \\
\hline & Alfenas & & 6.7 & & 38.9 & 45.6 & 28.6 \\
\hline & Careaçu & & 18.3 & & 51.3 & 69.6 & 44.8 \\
\hline \multicolumn{2}{|c|}{ Averages of all experiments } & & 40.6 & & 35.2 & 75.8 & 69.4 \\
\hline $\mathrm{C} 1$ & Carrancas & & 8.4 & & 13.5 & 21.9 & 22.5 \\
\hline \multirow{2}{*}{$\mathrm{C} 2$} & Lavras & & 9.0 & & 25.3 & 34.3 & 26.6 \\
\hline & São João da Mata & & 7.1 & & 22.2 & 29.3 & 21.4 \\
\hline \multirow{3}{*}{$\mathrm{C} 3$} & Lavras & $50 \%$ & 12.3 & $10 \%$ & 50.8 & 63.1 & 40.8 \\
\hline & Alfenas & & 4.3 & & 48.8 & 53.1 & 28.6 \\
\hline & Careaçu & & 11.5 & & 64.3 & 75.8 & 44.8 \\
\hline \multicolumn{2}{|c|}{ Averages of all experiments } & & 25.7 & & 44.2 & 69.9 & 69.4 \\
\hline $\mathrm{C} 1$ & Carrancas & & 14.5 & & 6.2 & 20.7 & 19.8 \\
\hline \multirow{2}{*}{$\mathrm{C} 2$} & Lavras & & 15.6 & & 11.5 & 27.1 & 24.3 \\
\hline & São João da Mata & & 12.3 & & 10.1 & 22.4 & 19.7 \\
\hline \multirow{3}{*}{$\mathrm{C} 3$} & Lavras & $20 \%$ & 21.3 & $50 \%$ & 23.1 & 44.4 & 38.4 \\
\hline & Alfenas & & 7.4 & & 22.2 & 29.6 & 28.3 \\
\hline & Careaçu & & 20.0 & & 29.3 & 49.3 & 43.0 \\
\hline \multicolumn{2}{|c|}{ Averages of all experiments } & & 44.6 & & 20.1 & 64.7 & 61.3 \\
\hline
\end{tabular}

To be continued... 
Table 3 - Continued...

\begin{tabular}{|c|c|c|c|c|c|c|c|}
\hline $\mathrm{C} 1$ & Carrancas & & 13.2 & & 7.5 & 20.7 & 19.8 \\
\hline \multirow[t]{2}{*}{$\mathrm{C} 2$} & Lavras & & 14.2 & & 13.9 & 28.1 & 24.3 \\
\hline & São João da Mata & & 11.2 & & 12.2 & 23.4 & 19.7 \\
\hline \multirow[t]{3}{*}{$\mathrm{C} 3$} & Lavras & $25 \%$ & 19.4 & $40 \%$ & 28.0 & 47.4 & 38.4 \\
\hline & Alfenas & & 6.7 & & 26.9 & 33.6 & 28.3 \\
\hline & Careaçu & & 18.3 & & 35.4 & 53.7 & 43.0 \\
\hline \multicolumn{2}{|c|}{ Averages of all experiments } & & 40.6 & & 24.3 & 64.9 & 61.3 \\
\hline $\mathrm{C} 1$ & Carrancas & & 10.1 & & 9.8 & 19.9 & 19.8 \\
\hline \multirow{2}{*}{$\mathrm{C} 2$} & Lavras & & 10.8 & & 18.3 & 29.1 & 24.3 \\
\hline & São João da Mata & & 8.5 & & 16.1 & 24.6 & 19.7 \\
\hline \multirow{3}{*}{ C3 } & Lavras & $40 \%$ & 14.8 & $25 \%$ & 36.8 & 51.6 & 38.4 \\
\hline & Alfenas & & 5.1 & & 35.4 & 40.5 & 28.3 \\
\hline & Careaçu & & 14.0 & & 46.6 & 60.6 & 43.0 \\
\hline \multicolumn{2}{|c|}{ Averages of all experiments } & & 31.0 & & 32.0 & 63.0 & 61.3 \\
\hline $\mathrm{C} 1$ & Carrancas & & 8.4 & & 10.8 & 19.2 & 19.8 \\
\hline \multirow{2}{*}{$\mathrm{C} 2$} & Lavras & & 9.0 & & 20.2 & 29.2 & 24.3 \\
\hline & São João da Mata & & 7.1 & & 17.7 & 24.8 & 19.7 \\
\hline \multirow{3}{*}{$\mathrm{C} 3$} & Lavras & $50 \%$ & 12.3 & $20 \%$ & 40.5 & 52.8 & 38.4 \\
\hline & Alfenas & & 4.3 & & 38.9 & 43.2 & 28.3 \\
\hline & Careaçu & & 11.5 & & 51.3 & 62.8 & 43.0 \\
\hline \multicolumn{2}{|c|}{ Averages of all experiments } & & 25.7 & & 35.2 & 60.9 & 61.3 \\
\hline
\end{tabular}

Among the intensities used in the selection methods, the gains were roughly similar (Table 3 ). However, when we estimated the percentage of families selected in early generations ( $\mathrm{C} 1$ through $\mathrm{C} 3$ ), it was noted that the coincidence of selected families is larger when the selection intensity between families is weaker (around 35-45\%) (Table 4). This indicates that if the breeder chooses to make the selection between and within families, he should prefer a weaker intensity of selection between families and stronger among clones within these families. In this study the number of families evaluated was relatively small (22 families).

The evaluation of a larger number of families is important, therefore allowing higher selection intensities to be applied and still maintaining a large number of families from which clonal selection would be held. According to Kimbeng and Cox (2003) in the sugar cane breeding the recommended selection intensities among families lie between $30 \%$ and $40 \%$. 
Table 4 - Percentage of coincidence of families selected for tuber yield in different generations.

\begin{tabular}{|c|c|c|c|c|c|c|}
\hline \multirow{2}{*}{$\begin{array}{c}\text { Selection } \\
\text { intensities }(\%)\end{array}$} & \multicolumn{3}{|c|}{ Selected Families } & \multicolumn{3}{|c|}{$\%$ of coincidence } \\
\hline & C1 & $\mathrm{C} 2$ & $\mathrm{C} 3$ & $\mathrm{C} 2$ and $\mathrm{C} 1$ & $\mathrm{C} 3$ and $\mathrm{C} 1$ & $\mathrm{C} 3$ and $\mathrm{C} 2$ \\
\hline 9.1 & 10,19 & 5,6 & 8,5 & 0.0 & 0.0 & 50.0 \\
\hline 18.2 & $10,19,1,11$ & $5,6,19,11$ & $8,5,6,18$ & 50.0 & 0.0 & 50.0 \\
\hline 27.3 & $10,19, \underset{5}{1}, 11,18$ & $\begin{array}{c}5,6,19,11,9 \\
18\end{array}$ & $8,5,6,18,9,11$ & 66.6 & 50.0 & 83.3 \\
\hline 36.4 & $\begin{array}{c}10,19,1,11,18 \\
5,8,9\end{array}$ & $\begin{array}{c}5,6,19,11,9 \\
18,1,8\end{array}$ & $\begin{array}{c}8,5,6,18,9,11 \\
10,19\end{array}$ & 87.5 & 75.0 & 87.5 \\
\hline 45.5 & $\begin{array}{c}10,19,1,11,18 \\
5,8,9,6,20\end{array}$ & $\begin{array}{l}5,6,19,11,9 \\
18,1,8,10,14\end{array}$ & $\begin{array}{c}8,5,6,18,9,11 \\
10,19,4,1\end{array}$ & 90.0 & 90.0 & 90.0 \\
\hline
\end{tabular}

\section{CONCLUSIONS}

Genetic variances were lower between families than within families, for all traits, but the heritabilities between families were almost always larger.

The selection of families was more efficient when based on the average of environments. The expected gains from selection between and within families were superior to gains from the combined selection in any intensity of selection.

The selection of families should have weaker intensity than selection among clones within families.

\section{ACKNOWLEDGEMENTS}

The authors are indebted to the Coordenação de Aperfeiçoamento de Pessoal de Nível Superior (CAPES) for a master fellowship and National Council for Scientific and Technological Development (CNPq) for a grant in research productivity and to the Research Foundation of the state of Minas Gerais (FAPEMIG) for partially funding this research.

\section{REFERENCES}

BRADSHAW, J.E. et al. Early-generation selection between and within pair crosses in potato (Solanum tuberosum subsp. tuberosum) breeding programme. Theoretical and Applied Genetics, v.97, p.1331-1339. 1998.

BRADSHAW, J. E.; TODD, D.; WILSON, R. N. Use of tuber progeny tests for genetical studies as part of a potato (Sonalum tuberosum subsp. tuberosum) breeding programme. Theoretical and Applied Genetics, v.100, p.772-781, 2000.

BRESSIANI, J.A.; VENCOVSKY, R.; BURNQUIST, W.L. Interação entre famílias de cana-de-açúcar e locais: efeito na resposta esperada com a seleção. Bragantia, v.61, p.110.2002 .

BUENO FILHO, J.S.S.; VENCOVSKY, R. Efficiency of combined selection over sequential selection in forest tree progeny trials. Silvae Genetica v.49, p.168-173. 2000.

DINIZ, M.C.D.R.; PINTO, C.A.B.P.; LAMBERT, E.S. Sample size for family evaluation in potato breeding programs. Ciência e Agrotecnologia, v.30, p. 277-282. 2006.

FALCONER, D.S.; MACKAY, T.F.C. Introduction to quantitative genetics. London, Longman, 1996. 464p.

FISHER, R.H.; YATES, F. Tabelas estatísticas para pesquisa em biologia, medicina e agricultura. São Paulo, 1971. 150p.

GOPAL, J. Progeny selection for agronomic characters in early generations of potato breeding programme.

Theoretical and Applied Genetics, v.95, p.307-311. 1997.

GOPAL, J. Between and within variation and family selection in potato breeding programmes. Journal of Genetics and Breeding, v.36, p.201-208, 2001.

JACKSON, P.A.; MCRAE, T.A.; HOGARTH, D.M. Selection of sugarcane families across variable environments. I. Sources of variation and an optimal selection index. Field Crops Research, v.43, p.109-118. 1995.

KIMBENG, C.A.; COX, M.C. Early generation selection of sugarcane families and clones in Australia: A review. Journal American Society of Sugarcane Technologists, v.23, p.20-39. 2003. 
LAMBERT, E.S.; PINTO, C.A.B.P.; MENEZES, C.B.

Potato improvement for tropical conditions. I: Analysis of stability. Crop Breeding and Applied Biotechnology, v.6, p.129-135. 2006 a.

\section{LAMBERT, E.S.; PINTO, C.A.B.P.; MENEZES, C.B.}

Potato improvement for tropical conditions. II:

Selection indices and efficiency of selection. Crop

Breeding and Applied Biotechnology, v.6, p.185-193. 2006b.

ORTIZ, R.; GOLMIRZAIE, A.M. Genotype x

environment interaction and selection in true potato seed breeding. Experimental Agriculture, v.40, p.99-107. 2004.

PAULA, R.C.; PIRES, I.E.; CRUZ, C.D. Considerações sobre alguns critérios de seleção aplicados em melhoramento florestal. Científica, v.26, p.243-256. 1998.

PIRES, I.E. et al. Índice de seleção combinada aplicado ao melhoramento genético de eucalipto. Revista Árvore, v.20, p.191-197. 1996.
RAMALHO, M.A.P.; FERREIRA, D.F.; OLIVEIRA, A.C. Experimentação em Genética e Melhoramento de Plantas. Lavras: UFLA, 2000. 326p.

SEKIOKA, T.T.; LAUER, F.I. Some estimates of genotype $\mathrm{x}$ environment interactions in potato variety tests. American Potato Journal, v.47, p.304-310. 1970.

SIMMONDS, N.W. Family selection in plant breeding. Euphytica, v.90, p.201-208. 1996.

SIMON, G.A.; PINTO, C.A.B.P.; BENITES, F.R.G. Seleção de famílias clonais de batata em diferentes ambientes. Ciência e Agrotecnologia, v. 33, n. 1, p. 164-169, 2009.

TAI, G.C.C. et al. Yield potential and genotypeenvironment interactions of tetraploid-diploid $(4 \mathrm{x}-2 \mathrm{x})$ potato hybrids. American Potato Journal, v.28, p.191199. 1981.

WRICKE, G.; WEBER, W.E. Quantitative genetics and selection in plant breeding. Berlin: Walter de Gruyter, 1986. 406p. 